\title{
The Pricing of Accruals Quality with Expected Returns: Vector Autoregression Return Decomposition Approach*
}

\author{
Sang-Giun YIM*
}

Received: February 11, 2020 Revised: February 28, 2020 Accepted: March 05, 2020.

\begin{abstract}
Purpose: This study reexamines the test on the pricing of accruals quality. Theory suggests that information risk is a priced risk factor. Using accruals quality as the proxy for information risk, researchers have tested the pricing of information risk. The results are inconsistent potentially because of the information shock in the realized returns that are used as the proxy for expected returns. Based on this argument, this study revisits this issue excluding information-shock-free measure of expected returns. Research design, data and methodology: This study estimates expected returns using the vector autoregression model. This method extracts information shocks more thoroughly than the methods in prior studies; therefore, the concern regarding information shock is minimized. As risk premiums are larger in recession periods than in expansion periods, recession and expansion subsamples were used to confirm the robustness of the main findings. For the pricing test, this study uses twostage cross-sectional regression. Results: Empirical results find evidence that accruals quality is a priced risk factor. Furthermore, this study finds that the pricing of accruals quality is observed only in recession periods. Conclusions: This study supports the argument that accruals quality, as well as the pricing of information risk, is a priced risk factor.
\end{abstract}

Keywords: Vector Autoregression, Return Decomposition, Accruals Quality, Cost of Equity.

JEL Classification Code: M41, M20, G12

\section{Introduction}

One of the most controversial issues in accounting literature is whether accruals quality (AQ) is a priced risk factor because of the inconsistency in empirical test results (Core, Guay, \& Verdi, 2008; Francis, LaFond, Olsson, \& Schipper, 2005; Ogneva, 2012; Lyle, 2019). Most of these studies test the AQ pricing using realized stock returns as the proxy for expected returns, which has two concerns. First, realized returns include unexpected information shocks that could be associated with AQ (Elton, 1999).

*This study is based on one essay of my dissertation. I thank my dissertation chair Woon Oh Jung and committee members Leeseok Hwan, Jong Hag Choi, Kyung-Ho Park, and Seung Yeon Lim for the guidance and support. I am also grateful to seminar participants at Seoul National University for their useful comments.

${ }^{* *}$ First Author and Corresponding Author. Assistant Professor, Faculty of College of Business Administration, Kookmin University, Republic of Korea [Postal Address: 77, Jeongneung-ro, Seongbukgu, Seoul, 02707, Republic of Korea]. Email: yimsg@kookmin.ac.kr ๑ Copyright: Korean Distribution Science Association (KODISA)

This is an Open Access article distributed under the terms of the Creative Commons Attribution NonCommercial License (https://creativecommons.org/licenses/by-nc/4.0/) which permits unrestricted noncommercial use, distribution, and reproduction in any medium, provided the original work is properly cited.
Second, prior studies match annual earnings to monthly returns. The difference in the measurement period could bias the test because the informativeness of earnings dissipates over time. Ogneva (2012) addresses the first concern by separating cash flow news from the proxy for expected returns. However, this method leaves another information shock, the discount rate news, in the proxy for expected returns. This study reinvestigates the pricing test of AQ by using an alternative proxy for expected returns that excludes both discount rate news and cash flow news.

Realized returns include expected returns and two information shocks, namely, cash flow news and discount rate news (Elton, 1999; Vuolteenaho, 2002). Among these, expected returns are supposed to be utilized in the pricing test. Ogneva (2012) suggests that prior tests of AQ pricing are inconsistent because of cash flow news in the realized return that are associated with AQ. Excluding cash flow news from realized return using earnings surprises, Ogneva (2012) revisits the AQ pricing test. However, her approach also left significant information shock in her proxy of expected returns.

This study reexamines AQ pricing with a sample of US public firm data from 1969 to 2012. This study measures 
AQ following Dechow and Dichev (2002) and McNichols (2002). The proxy of expected returns is estimated by the vector autoregression (VAR) model that controlled information shocks, namely, discount rate news and cash flow news, more thoroughly than prior AQ pricing tests (Vuolteenaho, 2002). This study uses annual returns to match the measurement frequency of accounting earnings and stock returns. The importance of information contents in announced earnings dissipates as time passes after earnings announcements; hence, the difference in measurement frequency could bias the proxy for expected returns.

Before the pricing test using two-stage cross-sectional regression, this study uses an ordinary least square regression. The firm-level pooled regression analysis shows that the estimated expected returns are positively related to the decile rank of AQ when the year-fixed effect is controlled. However, the positive relation becomes weaker after controlling the beta, book-to-market ratio, and the log of the market value of equity.

Using two-stage cross-sectional factor regressions, this study finds evidence of the pricing of returns on the AQ factor-mimicking portfolio (AQ_Factor), which is interpreted as the evidence of the AQ pricing. However, realized returns exhibit no significant positive risk premium for AQ. These test results show that using realized returns as the proxy for expected returns could bias the test for AQ pricing.

Prior studies suggest that the risk premium is larger in bad economic conditions. Following their argument, this study further examines whether the pricing is stronger in recession periods. By using the expectation model for market returns of Petkova and Zhang (2005), this study estimates the expected market premium and divides the sample periods into four groups by the quartiles of the expected market premium. The years in the first and fourth groups are classified as expansion periods and recession periods, respectively. Using the recession and expansion period subsamples, this study reruns the two-stage crosssectional factor regressions. The positive risk premium for AQ is observed only in the recession periods. The risk premium for $\mathrm{AQ}$ in the recession period is larger than that in the full sample period.

This study has several contributions. The results of this study add evidence supporting the argument that AQ is a priced risk factor. Despite the theory on the AQ pricing (Easley \& O'Hara, 2004), empirical studies on this subject report contradicting results. The results of this study strengthen the argument that information risk is a priced risk factor through the AQ pricing test. Second, this study shows that the choice of the proxy for expected returns can affect the results of asset pricing tests. Realized returns are the most widely used proxy of expected return in the pricing test. The economic difference between realized returns and expected returns is frequently ignored in the studies on asset pricing tests because several researchers have used realized returns. Ogneva (2012) points out the problem of using realized returns in the pricing test of accruals. This study provides evidence supporting the argument of Ogneva (2012). Third, this present study suggests and tests an alternative proxy for expected returns. Although this study's expected returns proxy is already known (Callen, Livnat, \& Segal, 2006; Callen \& Segal, 2004), few studies use the expected returns for the purpose other than calculating information shocks in the realized returns. The measure may not be perfect; however, this method provides the most thorough estimate to extract information shocks from expected returns.

The remainder of this paper proceeds as follows. Section 2 examines prior literature. Section 3 shows the research design and the VAR decomposition method. Section 4 presents the main empirical results. Section 5 presents additional test and its results. Finally, Section 6 concludes the paper.

\section{Literature Review}

\subsection{The Pricing of Accruals Quality}

Easley and O'Hara (2004) argue that uninformed investors are likely to require high returns for holding stocks with unequal information distribution due to the disadvantages in adjusting investment portfolios (Baimukhamedova, Baimukhamedova, \& Luchaninova, 2017). Moreover, they conjecture that this information risk is a priced risk factor because the risk is undiversifiable, and they specifically point out accounting information as an important information source to mitigate information risk.

Following this argument, Francis et al. (2005) test whether information risk is a priced risk factor by using AQ as the proxy for information risk. They focus on AQ because accruals contain information about future cash flows that are estimated based on managers' judgment. They found a significantly positive relation between AQ and realized returns in their firm-specific time-series regression. The positive relation is interpreted as evidence of the AQ pricing.

Core et al. (2008) refute Francis et al. (2005) by pointing out that firm-specific time-series regression is not an appropriate test method for asset pricing tests. By using two-stage cross-sectional regression, Core et al. (2008) reexamine the relation between excess returns and AQ. They fail to find evidence supporting AQ pricing and conclude that accrual quality is not a priced risk factor. 
Moreover, Core et al. (2008) use realized returns as the proxy for expected returns. Realized returns are widely used as the proxy for expected returns based on the premise that the differences between realized returns and expected returns, which are unexpected returns or information shocks, have no systematic and persistent components (Elton, 1999). Ogneva (2012) argues that the AQ measure is negatively associated with unexpected returns because the AQ is related to unexpected future economic events that reduce future cash flows. Based on the conjecture above, Ogneva (2012) revisits the AQ pricing. Using an earnings response coefficient model, Ogneva (2012) estimates cash flow stocks in realized returns and excludes cash flow stocks to obtain cash-flow-shock-free expected returns. Using this proxy, she finds evidence of AQ pricing in the two-stage cross-sectional regression analyses.

\subsection{Information Shocks and Accruals Quality}

A test of asset pricing should examine whether the factor of interest affects expected returns because this is required by market participants. However, studies on asset pricing frequently use realized returns by assuming that unexpected returns, which are information shocks, can be canceled out by using a long time series of returns. Elton (1999) suggests that the unexpected returns may not be canceled out over the sample period if the information shocks are significant in amount or correlated over time. Important economic events, for example, earnings surprise, could leave significant and persistent effects on stock returns (Ball, Gerakos, Linnainmaa, \& Nikolaev, 2016; Leila, Mahdi, \& Ali, 2014), which could bias the pricing test.

Previous studies find that AQ has a significant relation with future cash flows or discount rates. For example, low AQ firms are likely to have large sales growth in previous periods, volatile operating cash flows, and volatile sales. Those firms are also likely to report a loss in the following period (Dechow \& Dichev, 2002; Doyle, Ge, \& McVay, 2007). In addition, firms that have grown fast are likely to have volatile earnings, cash flows, and sales (Lakonishok, Shleifer, \& Vishny, 1994). Therefore, cash flows and sales are associated with poor stock performance (Mohanram, 2005); thus, AQ is also related to future stock performance (Dang \& Tran, 2019). These studies imply that low ex ante AQ is related to negative information shocks in the future. If $A Q$ is a proxy for undiversifiable information risk, the relation between AQ and information shocks could be canceled out during the pricing test. If not, as Ogneva (2012) argues, the association between AQ and information shock would bias the AQ pricing test.

Ogneva (2012) reexamines the AQ pricing after extracting the cash flow shocks from realized returns by using an earnings response coefficient model. Stock returns related to unexpected earnings are classified as cash flow shocks. Realized returns minus the cash flow shocks are used as the proxy for expected returns in her test for the AQ pricing.

Although the approach is reasonable, Ogneva's (2012) method poses concerns. First, this method does not exclude discount factor news from the proxy for expected returns. Prior studies suggest a potential relation between discount rate shocks and AQ (Dechow \& Dichev, 2002; Lakonishok et al., 1994). Second, Ogneva (2012) utilizes only accounting earnings to estimate cash flow shocks. Stock returns include all relevant information regardless of its format, whereas accounting earnings only recognize earnings defined by accounting standards. Therefore, using only accounting information could leave measurement errors in expected returns. Third, the method of Ogneva (2012) is inconsistent in terms of measurement frequency. Her study uses annual unexpected earnings as an input for the separation of cash flow shocks from realized monthly returns. Although the information contents of earnings surprises can take months to be fully incorporated into the stock price (Bernard \& Thomas, 1989, 1990), the magnitude of the impact of earnings surprise on unexpected returns dissipates as time passes. Thus, the inconsistency of measurement period between stock returns and accounting information could cause measurement errors.

The return decomposition method of Vuolteenaho (2002) can be an alternative. The method decomposes realized returns into three components: expected returns and two information shocks, namely, cash flow shocks and discount rate shocks. Vuolteenaho (2002) utilizes VAR to extract expected returns from realized returns. This method estimates expected returns using previous earning, stock return, and market-to-book ratio. The stock returns that are not explained by the autoregression model are defined as information shocks. Therefore, stock returns that are not explained by the factors are allocated to information shocks. On the contrary, Ogneva's (2012) model allocates returns that are not explained by earnings surprises to expected returns. Thus, Vuolteenaho's estimate for expected returns is more conservative and is likely to have fewer measurement errors.

This study shares Ogneva's point of view regarding the effect of information shock in the proxy for expected returns. However, to address the concerns in the work of Ogneva (2012), this study adopts the method of Vuolteenaho (2002) in estimating expected returns and revisits the pricing test of $A Q$.

\section{Research Design and Sample}

\subsection{Estimation of Accruals Quality Factor}


Unlike prior studies, this study examines AQ pricing using annual returns to avoid potential measure errors by matching the measurement frequencies of returns and accounting information.

The first-stage regression includes the returns on the AQ factor-mimicking portfolio ( $A Q$ factor) and the three factors of Fama and French (1993). AQ is calculated following the method of McNichols (2002).

$$
\begin{aligned}
& T C A_{i t}=\alpha_{t}+\beta_{1 t} C F O_{i t-1}+\beta_{2 t} C F O_{i t}+\beta_{3 t} C F O_{i t+1} \\
& \quad+\beta_{4 t} \Delta R E V_{i t}+\beta_{5 t} P P E_{i t}+\varepsilon_{i t}
\end{aligned}
$$

The variables are defined as follows:

$$
\begin{aligned}
& T C A=(\triangle C A-\triangle C a s h)-(\triangle C L-\triangle S T D E B T) \\
& \triangle C A=\text { change in current assets deflated by } \\
& \text { average total assets } \\
& \triangle \text { Cash }=\text { change in cash and short-term } \\
& \text { investments deflated by average total } \\
& \text { assets } \\
& \triangle C L=\text { change in current liabilities deflated by } \\
& \text { average total assets } \\
& \triangle S T D E B=\text { change in debt in current liabilities } \\
& T \quad \text { deflated by average total assets } \\
& \text { NIBE }=\text { income before extraordinary items } \\
& \text { deflated by average total assets } \\
& T A=T C A-D E P N \\
& D E P N=\text { depreciation and amortization deflated } \\
& \text { by average total assets } \\
& \text { CFO }=\text { NIBE }- \text { TA } \\
& \triangle R E V=\text { change in revenues deflated by average } \\
& \text { total assets } \\
& \text { PPE } \quad=\text { property, plant, and equipment deflated } \\
& \text { by average total assets }
\end{aligned}
$$

Using Fama and French's (1997) industry classification, this study employs industry-years having at least 20 observations in the estimation. The standard deviation of residuals $\left(\varepsilon_{\mathrm{it}}\right)$ of equation (1) from year $t-5$ to $t-1$ is defined as the AQ of firm $i$ at year $t$. To calculate $A Q$ factor, the following procedure is used (Francis et al., 2005). First, five portfolios were made based on the quintile rank of AQ for each year. Then, equal-weighted average annual stock returns are calculated for each portfolio. $A Q \_$factor is defined as the average of portfolio returns of the two bottom AQ quintiles (quintiles 4 and 5) minus the average of portfolio returns of the two upper AQ quintiles (quintiles 1 and 2) (Francis et al. 2005). The $A Q$ factor is measured annually using compounded monthly returns. Annualized market excess return is measured by subtracting the compounded Treasury bill rates from July of year $t$ to June of year $t+1$ from the compounded realized monthly market returns.

\subsection{Vector Autoregression Return Decomposition}

Vuolteenaho (2002) uses the following VAR model:

$$
z_{t+1}=\Gamma \cdot z_{t}+\eta_{t+1}
$$

Vector $\boldsymbol{z}_{t}$ has $\mathrm{k}$ elements that include stock return in the $\log$-linear form of year $t\left(r_{t}\right)$, return on equity of year $t\left(\right.$ roe $\left._{t}\right)$, and other determinants that affect the return on equity. In addition to $r_{t}$ and $r o e_{t}$, the model includes the book-tomarket ratio $\left(b m_{t}\right)$ as a proxy of aggregate risk. Equation (2) is estimated with the following model:

$$
\left(\begin{array}{c}
r_{t+1} \\
\operatorname{roe}_{t+1} \\
b m_{t+1}
\end{array}\right)=\left(\begin{array}{lll}
\alpha_{1} & \alpha_{2} & \alpha_{3} \\
\beta_{2} & \beta_{2} & \beta_{3} \\
\gamma_{1} & \gamma_{2} & \gamma_{3}
\end{array}\right)\left(\begin{array}{c}
r_{t} \\
\text { roe }_{t} \\
b m_{t}
\end{array}\right)+\left(\begin{array}{l}
\eta_{1 t+1} \\
\eta_{2 t+1} \\
\eta_{3 t+1}
\end{array}\right)
$$

Thus, the estimated expected returns of $t+1$ are calculated as

$$
\begin{aligned}
\begin{array}{r}
\hat{r}_{t+1}= \\
\text { where }
\end{array} & \hat{\alpha}_{1} r_{t}+\hat{\alpha}_{2} \text { roe }_{t}+\hat{\alpha}_{3} b m_{t} \\
r \quad & \text { the natural logarithm of } 1 \text { plus annual realized } \\
& \text { stock return less } 1 \text { plus } 30 \text {-day Treasury bill } \\
& \text { rate, demeaned by the } 48 \text { Fama-French } \\
\text { industry groups } & \text { the natural logarithm of } 1 \text { plus return on equity } \\
\text { roe }= & \text { less } 1 \text { plus } 30 \text {-day Treasury bill rate, demeaned } \\
& \text { by the } 48 \text { Fama-French industry groups } \\
\text { the natural logarithm of the book-to-market } & \text { value of equity ratio, demeaned by the } 48 \\
& \text { Fama-French industry groups }
\end{aligned}
$$

This study calculates the annualized stock returns by compounding monthly stock returns from July of year $t$ to June of year $t+1$. For the remaining details of the estimation, this study follows Callen and Segal (2010).

VAR return decomposition method utilizes surprises in $\boldsymbol{z}_{t}$ to estimate $\widehat{\mathbf{z}}_{t+1}$, meaning that the effect of information shocks in $\boldsymbol{z}_{t}$ is reflected in $\hat{\mathbf{z}}_{t+1}$. Once a type of the shock is estimated, the other shock is calculated residually. Hence, information shocks can be measured in two methods depending on which shock is estimated first. Campbell (1991) recommends calculating discount rate shocks directly with the residuals of the stock returns and companion matrix and then assigning the remaining part to cash flow shocks. Using equations (2) and (3), we can express the discount rate shock and cash flow shock, respectively, as 
$-\mathrm{N} r_{t}=-N_{1}^{\prime} \boldsymbol{\eta}_{t}$

$\mathrm{N} e_{t}=\left(\boldsymbol{e}_{1}+\boldsymbol{\lambda}_{1}\right)^{\prime} \boldsymbol{\eta}_{t}$

where $\boldsymbol{e}_{\boldsymbol{k}}^{\prime}=(0, \ldots 1, \ldots 0)$ and $\lambda_{k}^{\prime}=\boldsymbol{e}_{\boldsymbol{k}}^{\prime} \rho \Gamma(\mathbf{I}-\rho \Gamma)^{-1}$.

Alternatively, cash flow shocks can be calculated first. In this case, discount rate shocks include the remaining part.

$$
\begin{aligned}
& \mathrm{N} e_{t}=\left(\boldsymbol{e}_{2}^{\prime}+\lambda_{2}^{\prime}\right)^{\prime} \boldsymbol{\eta}_{t} \\
& -\mathrm{N} r_{t}=-\left(\boldsymbol{e}_{2}^{\prime}-\boldsymbol{e}_{\mathbf{1}}^{\prime}+\lambda_{2}^{\prime}\right) \boldsymbol{\eta}_{t}
\end{aligned}
$$

To check for robustness, this study calculates the shocks using both methods.

Unlike realized returns, expected returns from the VAR process address the concern that realized returns have significant information shocks. In addition, this method does not require assumptions for long-term growth rates compared with the implied cost of equity methods. Furthermore, this method is free from the bias in analyst forecasts.

\subsection{Sample}

The final sample consists of 70,440 firm-year observations, which contain accounting data from 1968 to 2010 and stock return data from 1969 to 2012, for 44 years. This study obtains the accounting data from Compustat and stock returns and market value of equity from the Center for Research in Security Prices database.

\section{Empirical Analysis}

\subsection{Descriptive Statistics}

Panels $\mathrm{A}$ and $\mathrm{B}$ of Table 1 present the descriptive statistics of firm-level variables and return on factors, respectively. Variable definitions are presented below.

\footnotetext{
$R f=$ annualized one-month Treasury bond rate

Rret $=$ annual realized excess stock returns

Eret $=$ expected return estimated by equation (4)

$-N r \_$est $=$discount rate shocks estimated by equation (5)

$N e \_r s d=$ residually calculated cash flow shocks by equation (6).

Ne_est $=$ cash flow shocks estimated by equation (7).

$-N r_{-} r s d=$ residually estimated discounted rate shock by equation (8).
}

The mean value of the realized excess return (Rret-Rf) is about $9.7 \%$, which is larger than the mean of expected return (Eret-Rf), 0.77\%. Ne_est ( $\left.-N r \_e s t\right)$ is cash flow shocks (discount rate shocks) estimated with coefficients of equation (2), and $N e \_r s d\left(-N r \_r s d\right)$ is residually calculated cash flow shocks (discount rate shocks). The standard deviation of Rret-Rf (48.98\%) is larger than that of Eret-Rf $(7.19 \%)$, which means that the volatility is assigned to information shocks.

In Panel B, the average of $A Q$ factor is $-0.26 \%$; however, the p-value is only 0.87 . The average of $A Q$ factor is not significantly different from zero, which is the same in prior studies (Core et al. 2008; Francis et al. 2005; Ogneva 2012).

Table 1: Descriptive Statistics

Panel A: Firm-Level Variables

\begin{tabular}{|l|r|r|r|r|r|r|}
\hline \multicolumn{1}{|c|}{ Variable } & Mean & \multicolumn{1}{c|}{ STD } & \multicolumn{1}{c|}{ Skew } & \multicolumn{1}{c|}{$\mathbf{1 5 \%}$} & $\mathbf{5 0 \%}$ & $\mathbf{7 5 \%}$ \\
\hline Rret-Rf & 9.68 & 48.98 & 1.87 & -20.61 & 2.74 & 30.02 \\
\hline Eret-Rf & 0.77 & 7.19 & 0.05 & -3.52 & 0.55 & 5.04 \\
\hline -Nr_est & 1.16 & 17.36 & 3.28 & -7.96 & -0.33 & 7.69 \\
\hline Ne_rsd & 8.67 & 39.59 & 1.81 & -15.07 & 3.66 & 25.51 \\
\hline -Nr_rsd & 7.93 & 123.27 & 83.09 & -17.47 & -1.88 & 16.30 \\
\hline Ne_est & 8.67 & 53.11 & 54.53 & -7.63 & 5.69 & 20.68 \\
\hline Beta & 1.09 & 0.65 & 0.79 & 0.66 & 1.04 & 1.44 \\
\hline ME & 2,199 & 11,642 & 17 & 31 & 154 & 845 \\
\hline B/M & 1.39 & 4.59 & 12.72 & 0.44 & 0.74 & 1.21 \\
\hline $\operatorname{lnME}$ & 5.15 & 2.25 & 0.24 & 3.44 & 5.04 & 6.74 \\
\hline $\ln (\mathrm{B} / \mathrm{M})$ & -0.29 & 0.89 & 0.74 & -0.83 & -0.30 & 0.19 \\
\hline RME & 4.52 & 2.82 & -0.01 & 2.00 & 5.00 & 7.00 \\
\hline R(B/M) & 4.52 & 2.82 & -0.01 & 2.00 & 5.00 & 7.00 \\
\hline
\end{tabular}

Panel B: Return on Factors

\begin{tabular}{|l|r|r|r|r|r|r|}
\hline $\begin{array}{l}\text { Factor } \\
\text { return }\end{array}$ & Mean & STD & $\mathbf{2 5 \%}$ & $\mathbf{5 0 \%}$ & $\mathbf{7 5 \%}$ & p-value \\
\hline$R^{A Q r}$ & -0.26 & 10.80 & -9.19 & -0.40 & 4.60 & $(0.87)$ \\
\hline$R^{M k t}-R f$ & 5.84 & 18.85 & -2.21 & 7.04 & 15.44 & $(0.04)$ \\
\hline$R^{H M L}$ & 0.02 & 43.57 & -5.57 & 4.45 & 15.87 & $(0.99)$ \\
\hline$R^{S M B}$ & 6.12 & 29.19 & -8.43 & -0.14 & 9.21 & $(0.17)$ \\
\hline
\end{tabular}

Note: All the returns are measured annually and presented in percentage unit.

\subsection{Return Components and Accruals Quality}

Before the main pricing test, using the single-stage pooled regression or Fama-McBeth regression, this study examines the characteristics of expected return proxy in its relation with AQ. Table 2 shows the mean values of components of realized returns by the decile rank of $\mathrm{AQ}$ 
(RAQ) for the full sample. Figures 1 and 2 depict the results in Table 2. Unlike Rret-Rf, Eret-Rf shows a generally increasing trend except for the 10th decile, but the increasing trend is weak. Moreover, discount rate shocks increase in RAQ, especially when these shocks are calculated residually ( $-\mathrm{Nr} \_$rsd). These results should be interpreted with caution because $-\mathrm{Nr}_{-}$rsd contains large measurement errors.

Table 2: Components of Stock Returns by AQ Decile

\begin{tabular}{|c|r|r|r|r|r|r|}
\hline RAQ & Rret-Rf & Eret-Rf & -Nr_est & Ne_rsd & -Nr_rsd & Ne_est \\
\hline 1 & 9.58 & 0.52 & 0.54 & 7.17 & 1.95 & 7.38 \\
\hline 2 & 10.16 & 0.56 & 1.18 & 8.67 & 5.02 & 8.66 \\
\hline 3 & 9.88 & 0.52 & 1.12 & 8.86 & 4.64 & 8.48 \\
\hline 4 & 9.80 & 0.74 & 0.86 & 8.96 & 5.43 & 9.62 \\
\hline 5 & 10.53 & 0.72 & 1.24 & 9.51 & 7.09 & 9.23 \\
\hline 6 & 9.97 & 0.93 & 0.99 & 9.12 & 8.26 & 8.64 \\
\hline 7 & 9.89 & 0.91 & 1.24 & 8.99 & 8.58 & 8.29 \\
\hline 8 & 9.94 & 1.08 & 0.74 & 9.37 & 7.55 & 8.65 \\
\hline 9 & 8.88 & 1.19 & 1.28 & 8.26 & 10.18 & 9.32 \\
\hline 10 & 8.13 & 0.50 & 2.37 & 7.74 & 20.55 & 8.43 \\
\hline
\end{tabular}

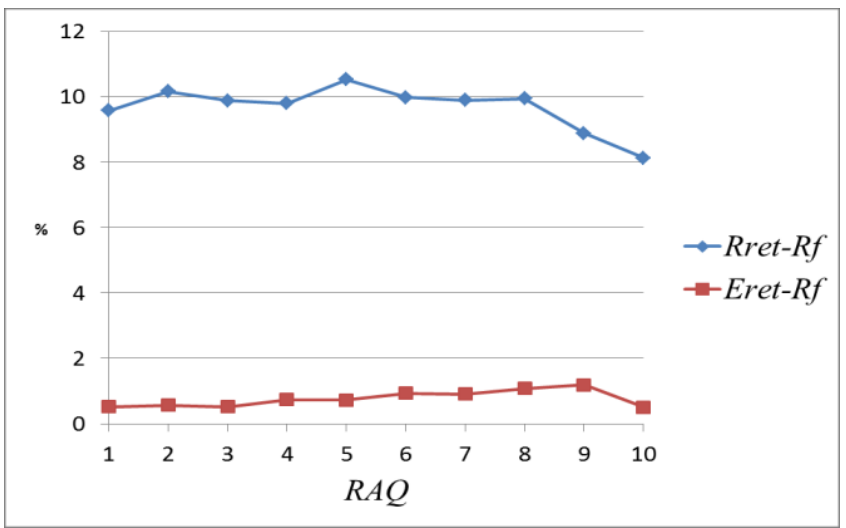

Figure 1: Realized Returns and Expected Returns by AQ Decile

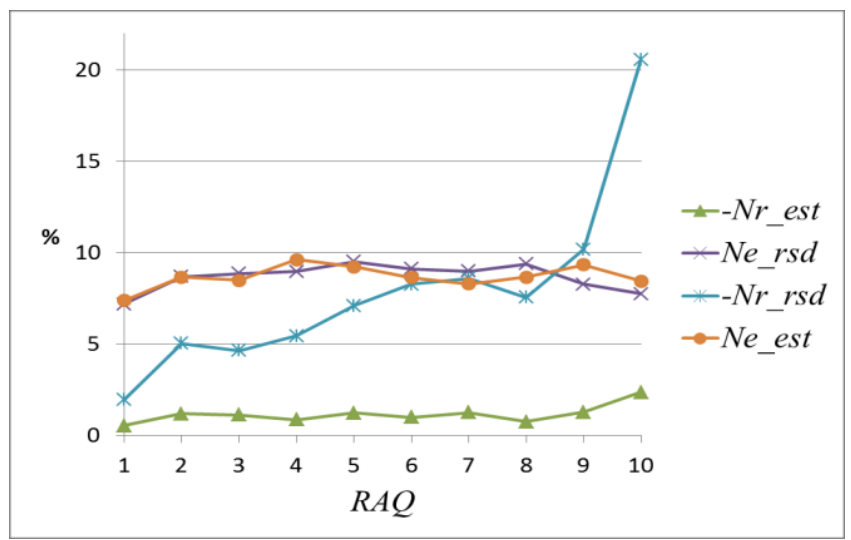

Figure 2: Information Shocks by AQ Decile
Before the main pricing test, this study examines the relation between $R A Q$ and return components. The model for pooled regression is

$$
\begin{aligned}
y_{i t+1}= & \alpha+\beta_{1} R A Q_{i t}+\beta_{2} \text { Beta }_{i t}+\beta_{3} M E_{i t}+\beta_{4} \ln \left(\frac{B}{M}\right)_{i t} \\
& +\sum \text { year_dummies } \\
+ & +\varepsilon_{i t+1}
\end{aligned}
$$

where $y_{i t+1}$ is Rret-Rf, Eret-Rf, $-N r \_e s t,-N r \_r s d, N e \_r s d$, or Ne_est. Among the subscripts, $i$ is the firm identifier, and $t$ denotes the year of observation. The pooled regression results are reported in Table 3.

Table 3: Pooled Regression

\begin{tabular}{|c|c|c|c|c|c|c|}
\hline & $\begin{array}{c}(1) \\
\text { Rret-Rf } \\
\end{array}$ & $\begin{array}{c}(2) \\
\text { Eret-Rf }\end{array}$ & $\begin{array}{c}(3) \\
-N r_{-} e s t \\
\end{array}$ & $\begin{array}{c}(4) \\
N e \_r s d \\
\end{array}$ & $\begin{array}{c}\text { (5) } \\
-N r_{-} r s d \\
\end{array}$ & $\begin{array}{c}\text { (6) } \\
\text { Ne_est }\end{array}$ \\
\hline$R A Q$ & $\begin{array}{c}0.61^{* * *} \\
(9.35)\end{array}$ & $\begin{array}{c}-0.01 \\
(-0.69)\end{array}$ & $\begin{array}{c}0.00 \\
(0.00)\end{array}$ & $\begin{array}{c}0.77 * * * \\
(13.81)\end{array}$ & $\begin{array}{l}0.43 * * \\
(2.53)\end{array}$ & $\begin{array}{c}0.64 * * * \\
(7.82)\end{array}$ \\
\hline Beta & $\begin{array}{c}-1.58^{* * *} \\
(-5.28)\end{array}$ & $\begin{array}{c}-0.58 * * * \\
(-9.76)\end{array}$ & $\begin{array}{l}0.31^{* *} \\
(2.51)\end{array}$ & $\begin{array}{c}-0.82^{* * *} \\
(-3.26)\end{array}$ & $\begin{array}{c}6.10^{* * * *} \\
(6.37)\end{array}$ & $\begin{array}{c}-0.17 \\
(-0.19)\end{array}$ \\
\hline $\ln M E$ & $\begin{array}{l}2.52^{* * * *} \\
(23.37)\end{array}$ & $\begin{array}{l}-0.43^{* * *} \\
(-13.18)\end{array}$ & $\begin{array}{c}-0.04 \\
(-0.65)\end{array}$ & $\begin{array}{l}2.57 * * * \\
(27.13)\end{array}$ & $\begin{array}{c}-1.86^{* * * *} \\
(-4.32)\end{array}$ & $\begin{array}{l}2.17^{* * * *} \\
(16.03)\end{array}$ \\
\hline $\ln (B / M)$ & $\begin{array}{l}-4.76^{* * *} \\
(-17.03)\end{array}$ & $\begin{array}{l}3.43 * * * \\
(28.74)\end{array}$ & $\begin{array}{l}-5.75^{* * * *} \\
(-28.10)\end{array}$ & $\begin{array}{l}-3.10^{* * * *} \\
(-13.18)\end{array}$ & $\begin{array}{l}-12.23 * * * \\
(-11.33)\end{array}$ & $\begin{array}{l}-4.90^{* * *} \\
(-14.02)\end{array}$ \\
\hline $\begin{array}{l}\text { Year } \\
\text { Dummy }\end{array}$ & Yes & Yes & Yes & Yes & Yes & Yes \\
\hline Obs. & 70,440 & 70,440 & 70,440 & 70,440 & 70,440 & 70,440 \\
\hline Adj. R2 & 0.219 & 0.393 & 0.191 & 0.183 & 0.020 & 0.048 \\
\hline
\end{tabular}

Panel A: Return Components on AQ Decile

Panel B: Alternative Control Variables

\begin{tabular}{|l|c|c|c|c|}
\hline & $\begin{array}{c}(\mathbf{1}) \\
\text { Rret-Rf }\end{array}$ & $\begin{array}{c}(\mathbf{2}) \\
\text { Rret-Rf }\end{array}$ & $\begin{array}{c}(3) \\
\text { Eret-Rf }\end{array}$ & $\begin{array}{c}(4) \\
\text { Eret-Rf }\end{array}$ \\
\hline$R A Q$ & $0.42^{* * *}$ & -0.08 & 0.01 & $0.08^{* * *}$ \\
& $(6.84)$ & $(-1.37)$ & $(1.10)$ & $(4.84)$ \\
\hline Beta & $-1.63^{* * *}$ & -0.38 & $-0.65^{* * *}$ & $-1.13^{* * *}$ \\
& $(-5.49)$ & $(-1.27)$ & $(-12.42)$ & $(-15.35)$ \\
\hline$R M E$ & $1.47^{* * *}$ & & $-0.11^{* * *}$ & \\
& $(22.38)$ & & $(-7.17)$ & \\
\hline$R(B / M)$ & $-1.50^{* * *}$ & & $1.28^{* * *}$ & \\
& $(-23.75)$ & & $(76.20)$ & \\
\hline$M E$ & & $0.00^{* * *}$ & & $-0.00^{* * *}$ \\
& & $(4.21)$ & & $(-5.83)$ \\
\hline$B / M$ & & $-0.23^{* * *}$ & & $0.13^{* * *}$ \\
& & $(-6.09)$ & & $(8.19)$ \\
\hline Year Dummy & Yes & Yes & Yes & Yes \\
\hline Observations & 70,440 & 70,440 & 70,440 & 70,440 \\
\hline Adj. R2 & 0.217 & 0.199 & 0.457 & 0.200 \\
\hline
\end{tabular}

Note: The pooled regression results, coefficients, and statistical significance are presented in this table. $*, * *$, and $* * *$ denote two-tailed significance at $10 \%, 5 \%$, and $1 \%$, respectively. Firm-cluster adjusted tstatistics are in the parentheses.

Variable definition is documented below. 


$\begin{array}{lll}M E & = & \text { market value of equity (in million dollars) } \\ \ln M E & = & \text { the natural logarithms of } M E \\ R M E & = & \text { the annual decile rank of } M E \\ B / M & = & \text { book value of equity to market value of } \\ & \text { equity }\end{array}$

$R A Q$ is not significantly associated with Eret $-R f$ but is positively related to Rret-Rf. This study further examines this conjecture with different sets of control variables after replacing $\ln M E$ and $\ln (B / M)$ with the raw values of the market value of equity $(M E)$ and the book-to-market ratio $(B / M)$ or with the decile ranks of the market value of equity $(M E)$ and the book-to-market ratio $(R(B / M))$.

To check the influence of control variables, this study conducts a regression again after replacing the control variables. The results are presented in Panel B. In columns (1) and (3), when decile ranks $(R M E$ and $R(B / M))$ are included as control variable, the results are consistent with the results in Panel A. However, when raw values are controlled, $R A Q$ is insignificant in the regression for
Rret-Rf, but it is positively significant in the regression with Eret $-R f$. Untabulated results show that the inclusion of $\ln M E$ or $R M E$ is critical in the inconsistent significance of the coefficients of $R A Q$. However, the choice of the related variables of book-to-market ratio does not affect the coefficients of $R A Q$ significantly.

Overall, pooled regression in Table 3 shows inconsistent results, which are affected by the use of control variables for firm size. Descriptive statistics show that $M E$ is strongly right-skewed. Controlling the skewness by taking the logarithm value or using decile rank affects the significance of the coefficient of $R A Q$.

To examine the time trend of the relation between $R A Q$ and the two expected return proxies, this study estimates equation (9) for each year by using $R r e t-R f$ and Eret $-R f$ as the dependent variable and presents the coefficients of $R A Q$ in Figure 3. The coefficients of $R A Q$ in the regression for Rret $-R f$, which are generally positive, are more volatile than that in the regression for Eret-Rf. This is consistent with the regression results in Panel $B$ of Table 3 . Meanwhile, the coefficients of $R A Q$ for Eret-Rf are persistently close to zero. The high volatility of the coefficients of $R A Q$ for $R r e t-R f$ shows the impact of information shocks.

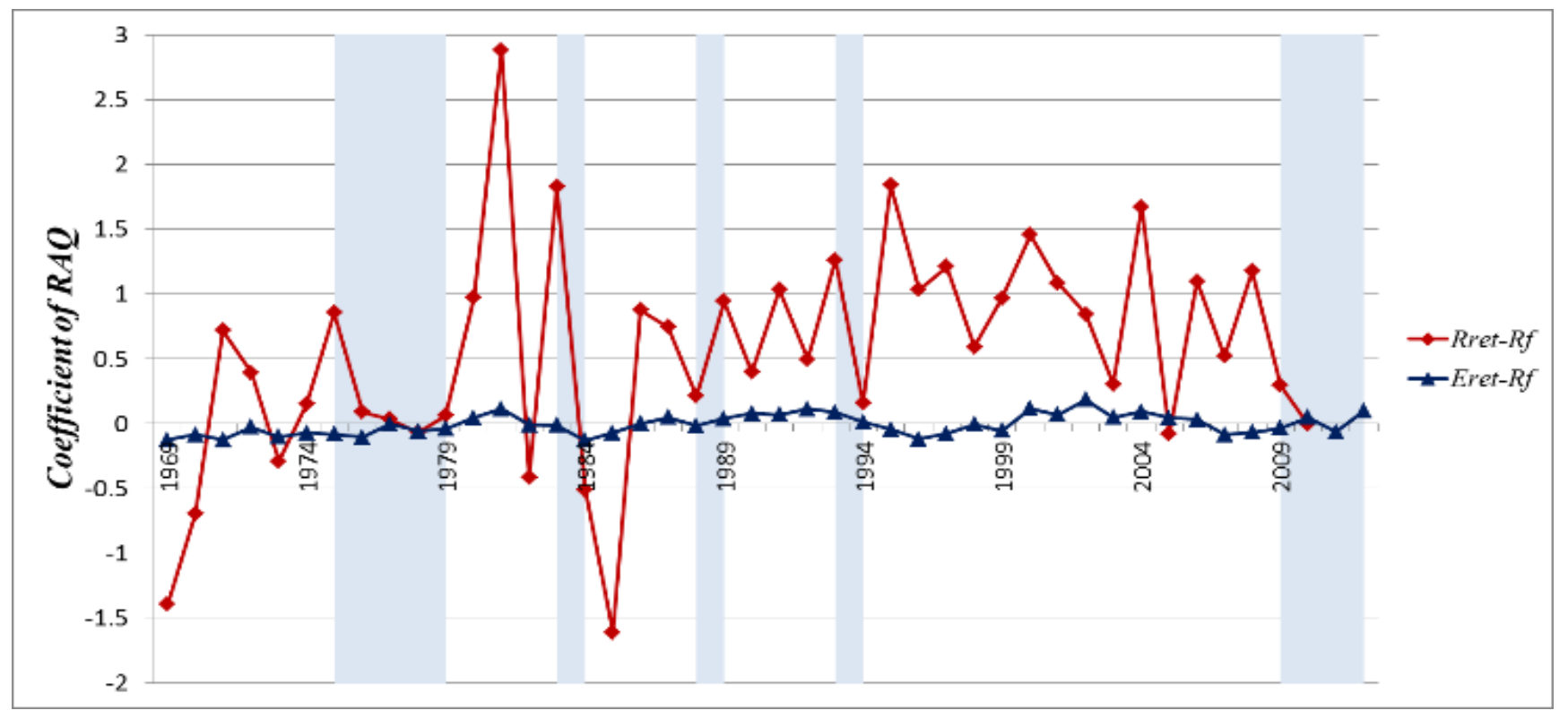

Figure 3: The Time Trend of the Coefficients of $R A Q$

To confirm that the results in Table 3 are not driven by the cross-sectional correlation of returns, this study reruns equation (4) using Fama-MacBeth regressions. The results are summarized in Table 4, which are generally consistent with the results in Table 3.

The relationship between information shocks and $R A Q$ is also examined through regression analyses. Columns (3)-(6) in Panel A of Table 3 provide the results. The coefficients of $R A Q$ are non-negative values, meaning that the positive coefficient of $R A Q$ in column (1) could be driven by information shocks. This is opposite to the conjecture of Ogneva (2012) who states that AQ is negatively related to 
future information shocks. The inconsistency could be due to the difference in decomposition approaches. Ogneva (2012) defines cash flow shocks narrowly; therefore, the stock reactions not related to unexpected accounting earnings are left in the proxy for expected returns. Meanwhile, the VAR decomposition estimated expected returns using market information and accounting information, and residuals are allocated to information shocks, which are either cash flow news or discount rate news. Accounting information explains only a small portion of the variance in realized stock returns; therefore, Ogneva's (2012) proxy of expected returns would have more information shocks than the proxy of expected return in this study.

Table 4: Fama-McBeth Regression

\begin{tabular}{|c|c|c|c|c|c|c|}
\hline & $\mathbf{( 1 )}$ & $\mathbf{( 2 )}$ & $\mathbf{( 3 )}$ & $\mathbf{( 4 )}$ & $\mathbf{( 5 )}$ & $\mathbf{( 6 )}$ \\
& Rret-Rf & Rret-Rf & Rret-Rf & Eret-Rf & Eret-Rf & Eret-Rf \\
\hline RAQ & $0.57^{* * *}$ & $0.39^{* *}$ & -0.10 & -0.01 & 0.01 & $0.06^{* *}$ \\
& $(4.51)$ & $(2.47)$ & $(-0.54)$ & $(-0.59)$ & $(0.74)$ & $(2.66)$ \\
\hline Beta & -2.33 & -2.42 & -0.97 & $-0.43^{* * *}$ & $-0.61^{* * *}$ & $-1.07 * * *$ \\
& $(-1.22)$ & $(-1.21)$ & $(-0.48)$ & $(-2.82)$ & $(-3.90)$ & $(-6.26)$ \\
\hline InME & $2.44^{* * *}$ & & & $-0.35^{* * *}$ & & \\
& $(5.84)$ & & & $(-6.39)$ & & \\
\hline ln(B/M) & $-4.86^{* * *}$ & & & $3.80^{* * *}$ & & \\
& $(-5.17)$ & & & $(23.25)$ & & \\
\hline$R M E$ & & $1.50^{* * *}$ & & & $-0.10^{* * *}$ & \\
& & $(6.38)$ & & & $(-3.87)$ & \\
\hline$R(B / M)$ & & $-1.41^{* * *}$ & & & $1.27^{* * *}$ & \\
& & $(-7.41)$ & & & $(62.23)$ & \\
\hline ME & & & 0.00 & & & $-0.00^{* * *}$ \\
& & & $(1.39)$ & & & $(-5.52)$ \\
\hline B/M & & & $-0.56^{* * *}$ & & & $0.38^{* * *}$ \\
& & & $(-4.04)$ & & & $(5.69)$ \\
\hline Const. & $-6.73^{*}$ & $8.06^{* * *}$ & $10.18^{* * *}$ & $4.04^{* * *}$ & $-3.98^{* * *}$ & $1.18^{* * *}$ \\
& $(-1.86)$ & $(3.02)$ & $(4.48)$ & $(9.79)$ & $(-9.80)$ & $(2.78)$ \\
\hline \# of Obs. & 70,440 & 70,440 & 70,440 & 70,440 & 70,440 & 70,440 \\
\hline R2 & 0.103 & 0.091 & 0.056 & 0.301 & 0.363 & 0.058 \\
\hline
\end{tabular}

Note: Firm-level Fama-MacBeth regression results, coefficients, and statistical significance are presented in this table. *, **, and *** denote two-tailed significance at $10 \%, 5 \%$, and $1 \%$, respectively. Fama-Mac-Beth t-statistics are in parentheses.

\subsection{Pricing Test}

The pricing of risk factors should be tested by examining whether the proxy for expected returns is positively related to the covariance between the risk factors and the proxy for expected returns, following a two-step process (Core et al.,
2008). This study examines the pricing of AQ by two-stage cross-sectional regressions. The first stage model is

$$
\begin{aligned}
& \left(\operatorname{Rret}_{p t}-R f_{t}\right) \operatorname{or}\left(\text { Eret }_{p t}-R f_{t}\right)=\alpha+\beta^{A Q} R_{t}^{A Q}+\beta^{M k t} R_{t}^{M k t} \\
& \quad+\beta^{S M B} R_{t}^{S M B}+\beta^{H M L} R_{t}^{H M L}+\varepsilon_{p t} .
\end{aligned}
$$

Rret $_{p t}$ and Eret $_{p t}$ are equal-weighted realized returns and expected returns on portfolio $p$, respectively. This study uses two sets of test portfolios: (1) 25 portfolios by independently sorted size and book-to-market quintiles; and (2) 64 portfolios by independently sorted size, book-tomarket quintiles, and $\mathrm{AQ}$ quartiles. The independent variables of equation (10), $R_{t}^{A Q}, R_{t}^{S M B}$, and $R_{t}^{H M L}$, are returns on the $\mathrm{AQ}$ factor-mimicking portfolio, market value of equity, and book-to-market ratio, respectively. The remaining details of pricing tests follow prior studies (Fama $\&$ French, 1993; Francis et al., 2005). The coefficients of equation (10), $\hat{\beta}^{A Q}, \hat{\beta}^{M k t}, \hat{\beta}^{S M B}$, and $\hat{\beta}^{H M L}$, are estimated by time series regressions of each portfolio. This study cross-sectionally estimates the second-stage model using the coefficients of equation (10) as independent variables. The second-stage regression model is

$$
\begin{aligned}
\left(\overline{\operatorname{Rret}}_{p t}\right. & \left.-R f_{t}\right) \operatorname{or}\left(\overline{\operatorname{Eret}}_{p t}-R f_{t}\right)=\alpha+\hat{\beta}_{P}^{A Q} R_{t}^{A Q}+\hat{\beta}_{P}^{M k t} R_{t}^{M k t} \\
& +\hat{\beta}_{P}^{S M B} R_{t}^{S M B}+\hat{\beta}_{P}^{H M L} R_{t}^{H M L}+\varepsilon_{p t}
\end{aligned}
$$

where the coefficients of $\hat{R}_{t}^{A Q}, \hat{R}_{t}^{M k t}, \hat{R}_{t}^{S M B}$, and $\hat{R}_{t}^{H M L}$ indicate the pricing of risk factors. The statistical significance of each coefficient is measured using FamaMcBeth t-statistics.

Table 5 shows the results of the second-stage regressions. The definitions of variables are as follows.

$\begin{aligned} R^{A Q}= & \text { annual returns on the } A Q \text { factor-mimicking } \\ & \text { portfolio in percentage. } \\ R^{M k t}-R f= & \text { annual excess returns on the market } \\ & \text { portfolio in percentage. } \\ R^{H M L}= & \text { annual returns on the size factor- } \\ & \text { mimicking portfolio following the } \\ & \text { calculation of Fama and French (1993). } \\ = & \text { annual returns on the book-to-market } \\ & \text { factor-mimicking portfolio following the } \\ & \text { calculation of Fama and French (1993). }\end{aligned}$

In the regressions using realized returns as the dependent variable, $\hat{\beta}_{P}^{A Q}$ is negatively related to realized returns, which is opposite to the prediction of accounting theory. Meanwhile, in the regressions using expected return, $\hat{\beta}_{P}^{A Q}$ has positive coefficients, supporting the pricing of $\mathrm{AQ}$. These results support the argument of Ogneva (2012) and are robust to the use of the portfolio for the pricing test. 
Table 5: Portfolio Factor Regression

\begin{tabular}{|c|c|c|c|c|}
\hline & \multicolumn{2}{|c|}{$M E-B / M(5 \times 5)$} & \multicolumn{2}{|c|}{$M E-B / M-A Q(4 \times 4 \times 4)$} \\
\hline & $\begin{array}{c}(1) \\
\text { Rret-Rf }\end{array}$ & $\begin{array}{c}(2) \\
\text { Eret-Rf }\end{array}$ & $\begin{array}{c}\text { (3) } \\
\text { Rret-Rf }\end{array}$ & $\begin{array}{c}\text { (4) } \\
\text { Eret-Rf }\end{array}$ \\
\hline$\hat{\beta}^{A Q}$ & $\begin{array}{c}-0.16 * * * \\
(-5.18)\end{array}$ & $\begin{array}{c}0.03^{* * *} \\
(5.85)\end{array}$ & $\begin{array}{c}-0.10^{* * *} \\
(-3.06)\end{array}$ & $\begin{array}{c}0.03 * * * \\
(5.80)\end{array}$ \\
\hline$\hat{\beta}^{M k t R f}$ & $\begin{array}{l}-0.05^{*} \\
(-2.54)\end{array}$ & $\begin{array}{c}0.15^{* * * *} \\
(4.68)\end{array}$ & $\begin{array}{c}-0.01 \\
(-0.44)\end{array}$ & $\begin{array}{l}0.08^{* *} \\
(2.84)\end{array}$ \\
\hline$\hat{\beta}^{S M B}$ & $\begin{array}{c}-0.40^{* * * *} \\
(-6.77) \\
\end{array}$ & $\begin{array}{r}2.00 * * * \\
(27.28) \\
\end{array}$ & $\begin{array}{c}-0.24 * * * \\
(-4.45) \\
\end{array}$ & $\begin{array}{c}-0.04 \\
(-0.71) \\
\end{array}$ \\
\hline$\hat{\beta}^{H M L}$ & $\begin{array}{l}0.99 * * \\
(6.96)\end{array}$ & $\begin{array}{l}-2.52 * * * \\
(-25.24)\end{array}$ & $\begin{array}{c}0.53^{* * *} \\
(7.53)\end{array}$ & $\begin{array}{r}-1.84 * * * \\
(-23.38)\end{array}$ \\
\hline Const. & $\begin{array}{c}-1.87 * * * \\
(-9.07)\end{array}$ & $\begin{array}{l}6.17 * * * \\
(36.40)\end{array}$ & $\begin{array}{c}-1.07 * * * \\
(-8.30)\end{array}$ & $\begin{array}{l}4.03 * * * \\
(31.68)\end{array}$ \\
\hline R2 & 0.471 & 0.534 & 0.264 & 0.270 \\
\hline $\begin{array}{l}\# \text { of } \\
\text { groups }\end{array}$ & 44 & 44 & 44 & 44 \\
\hline
\end{tabular}

Note: Table 5 reports the second-stage regression results of the two-stage cross-sectional regression by market condition. The first-stage regression model is presented in equation (10). Using the estimated coefficients of the first-stage time series regression, the second-stage cross-sectional regression is estimated with equation (11). Columns (1) and (2) report the results using 25 size and book-to-market portfolios, whereas columns (3) and (4) report the results using 64 size, book-to-market, and AQ portfolios. The table shows coefficients and statistical significance. *, **, and *** denote two-tailed significance at $10 \%, 5 \%$, and $1 \%$, respectively. FamaMacBeth t-statistics are in the parentheses.

\section{Additional Analysis}

Prior studies suggest that risk premiums are larger in recession periods than in expansion periods (Sohn \& Liu, 2015). If the results in Table 5 are due to the pricing of information risk, the premium on $\mathrm{AQ}$ factor should be larger in recession periods. To test this conjecture, this study reexamines the two-stage cross-sectional regression by dividing the sample by economic conditions using the method of Petkova and Zhang (2005), where the expected market return is used as the criterion of macroeconomic conditions.

First, following Petkova and Zhang (2005), this study calculates the expected market returns by estimating the model by month:

$$
\begin{aligned}
R_{m \varpi}= & \delta_{0}+\delta_{1} D I V_{\varpi-1}+\delta_{2} D E F_{\varpi-1}+\delta_{3} T E R M_{\varpi-1} \\
& +\delta_{4} R f_{\varpi-1}+\varepsilon_{m \varpi}
\end{aligned}
$$

where $R_{m}$ is the excess market returns and $T B$ is the 30-day Treasury bill rate. $D I V$ is the cash dividends payment of the entire Compustat database for the recent year divided by the total market value of all the firms in the Compustat database of the previous year. $D E F$ is the difference between the yields of 10-year and 1-year Treasury bonds, and TERM is the difference between the yields of AAA rate and BAA rate corporate bonds.

The monthly expected market premium is defined as follows:

$$
\begin{aligned}
\hat{R}_{m \varpi}= & \hat{\delta}_{0}+\hat{\delta}_{1} D I V_{\varpi-1}+\hat{\delta}_{2} D E F_{\varpi-1}+\hat{\delta}_{3} T E R M_{\varpi-1} \\
& +\hat{\delta}_{4} R f_{\varpi-1} .
\end{aligned}
$$

The annualized expected market premium for year $\varpi$ is calculated by compounding the monthly expected market premium for 12 months from July of year $\varpi^{-1}$ to June of year $\varpi$. The expected market premium increases (decreases) as the expectation about market condition becomes more pessimistic (optimistic). This study classifies years with an expected market premium in the first and fourth quartile rank as expansion and recession periods, respectively. Then, this study reruns the two-stage cross-sectional regression

\begin{tabular}{|c|c|c|c|c|}
\hline & \multicolumn{2}{|c|}{$M E-B / M(5 \times 5)$} & \multicolumn{2}{|c|}{$M E-B / M-A Q(4 \times 4 \times 4)$} \\
\hline & (1) & (2) & (3) & (4) \\
\hline & Rret-Rf & Eret-Rf & Rret-Rf & Eret-Rf \\
\hline \multirow[t]{2}{*}{$\hat{\beta}^{A Q}$} & 0.06 & $0.86^{* * *}$ & 0.06 & $0.15^{* * *}$ \\
\hline & $(1.68)$ & $(14.87)$ & (1.68) & $(4.10)$ \\
\hline \multirow[t]{2}{*}{$\hat{\beta}^{M k t R f}$} & $-0.14 * * *$ & $-0.57 * *$ & -0.04 & $-0.17 * * *$ \\
\hline & $(-3.07)$ & $(-7.63)$ & $(-0.94)$ & $(-3.82)$ \\
\hline \multirow[t]{2}{*}{$\hat{\beta}^{S M B}$} & $-0.11 * *$ & $-0.28 * * *$ & -0.05 & 0.04 \\
\hline & $(-2.49)$ & $(-5.98)$ & $(-1.06)$ & $(0.97)$ \\
\hline \multirow[t]{2}{*}{$\hat{\beta}^{H M L}$} & 0.01 & $0.39^{* * *}$ & 0.02 & -0.01 \\
\hline & $(0.29)$ & $(7.20)$ & $(0.58)$ & $(-0.29)$ \\
\hline \multirow[t]{2}{*}{ Const. } & -0.09 & $-0.06 * * *$ & 0.01 & -0.00 \\
\hline & $(-1.07)$ & $(-8.26)$ & $(0.11)$ & $(-0.48)$ \\
\hline $\mathrm{R} 2$ & 0.493 & 0.144 & 0.435 & 0.270 \\
\hline $\begin{array}{l}\# \text { of } \\
\text { groups }\end{array}$ & 11 & 11 & 11 & 11 \\
\hline
\end{tabular}
using only the expansion and recession period subsamples.

Table 6: Portfolio Factor Regression by Market Condition

\begin{tabular}{|c|c|c|c|c|}
\hline & \multicolumn{2}{|c|}{$M E-B / M(5 \times 5)$} & \multicolumn{2}{|c|}{$M E-B / M-A Q(4 \times 4 \times 4)$} \\
\hline & $\begin{array}{c}\text { (1) } \\
\text { Rret-Rf }\end{array}$ & $\begin{array}{c}\text { (2) } \\
\text { Eret-Rf }\end{array}$ & $\begin{array}{c}\text { (3) } \\
\text { Rret-Rf }\end{array}$ & $\begin{array}{c}(4) \\
\text { Eret-Rf }\end{array}$ \\
\hline$\hat{\beta}^{A Q}$ & $\begin{array}{c}-0.02 \\
(-0.52)\end{array}$ & $\begin{array}{c}-0.03 \\
(-0.68)\end{array}$ & $\begin{array}{c}0.01 \\
(0.20)\end{array}$ & $\begin{array}{c}-0.12 * * * \\
(-3.14)\end{array}$ \\
\hline$\hat{\beta}^{M k t R f}$ & $\begin{array}{c}-0.06 \\
(-0.67)\end{array}$ & $\begin{array}{c}-0.85 * * * \\
(-7.23)\end{array}$ & $\begin{array}{c}-0.02 \\
(-0.27)\end{array}$ & $\begin{array}{c}-0.33 * * * \\
(-4.12)\end{array}$ \\
\hline$\hat{\beta}^{S M B}$ & $\begin{array}{c}0.39 * * * \\
(4.88)\end{array}$ & $\begin{array}{c}0.13 \\
(1.59)\end{array}$ & $\begin{array}{l}0.19 * * \\
(2.46)\end{array}$ & $\begin{array}{c}0.09 \\
(1.04)\end{array}$ \\
\hline$\hat{\beta}^{H M L}$ & $\begin{array}{c}0.12 \\
(1.63)\end{array}$ & $\begin{array}{c}0.74 * * * \\
(8.97)\end{array}$ & $\begin{array}{c}0.01 \\
(0.18)\end{array}$ & $\begin{array}{c}0.22 * * * \\
(3.13)\end{array}$ \\
\hline Const. & $\begin{array}{c}0.13 * * * \\
(3.04)\end{array}$ & $\begin{array}{c}-0.04 * * * \\
(-13.06)\end{array}$ & $\begin{array}{l}0.05^{*} \\
(1.98)\end{array}$ & $\begin{array}{c}-0.02 * * * \\
(-12.74)\end{array}$ \\
\hline R2 & 0.498 & 0.084 & 0.394 & 0.165 \\
\hline $\begin{array}{l}\# \text { of } \\
\text { groups }\end{array}$ & 11 & 11 & 11 & 11 \\
\hline
\end{tabular}
Panel A: Recession Period

Panel B: Expansion Period 
Note: Table 6 reports the second-stage regression results of the two-stage cross-sectional regression by market condition. If the annualized expected market premium, measured by equation (12), is in the first (fourth) decile, the year is classified as an expansion (recession) period. Panels A and B report the results of the recession and expansion periods, respectively. The first-stage regression model is calculated using equation (10). Using the estimated coefficients of the first-stage time series regression, this study estimates the second-stage cross-sectional regression with equation (11). Columns (1) and (2) report the results using 25 size and book-to-market portfolios, whereas columns (3) and (4) report the results using 64 size, book-to-market, and AQ portfolios. The table shows coefficients and statistical significance. $*, * *$, and $* * *$ denote two-tailed significance at $10 \%, 5 \%$, and $1 \%$, respectively. Fama-MacBeth t-statistics are in parentheses.

Panel A of Table 6 summarizes the results. In the recession period, $\hat{\beta}^{A Q}$ is positively related to expected returns regardless of the portfolio for the test. However, realized returns do not have significant relation with $\hat{\beta}^{A Q}$. Furthermore, in the expansion period, the coefficients of $\hat{\beta}^{A Q}$ are insignificant or negative. Overall, the evidence of AQ pricing is found only in the recession period, which is consistent with the argument that the risk premium is larger in recession periods. In addition, the results also support that the significantly positive coefficient of $\hat{\beta}^{A Q}$ is due to the pricing of risks that are related to AQ.

\section{Conclusion}

Information shocks in realized returns are related to accruals, which could bias the AQ pricing test when realized returns are applied as the proxy of expected returns. By using a VAR model, the proxy of this study excludes information shocks from expected return more thoroughly than prior studies. Using this method, this study reinvestigates whether $\mathrm{AQ}$ is a priced risk factor. Moreover, the results find evidence of AQ pricing using two-stage cross-sectional regressions. The evidence of pricing is strong in the market recession period. Considering the fact that risk premium should be large when the recession is expected, the results of this study support the AQ pricing.

This study has some implications for pricing tests. Researchers assume that the information shocks in realized returns can be ignored in the test. However, the shocks are not random noise; therefore, the shocks can affect the result of a pricing test. This study calls attention to the potential bias of pricing test due to the information shocks in realized returns. In addition, this study implies that managers can improve firm valuation by providing high-quality accounting information. The impact of accounting quality on market participants are well known (Nam, 2019). However, the impact of accounting quality on valuation requires more investigation (Chae, Nakano, \& Fujitani,
2020). This study shows that high-quality accounting can improve firm valuation by reducing information risk, which suggests the reason to improve accounting quality.

This study has several limitations. In opposition to the method of Ogneva (2012), the method of this study might estimate expected returns too tightly, and thus, information shocks might be narrowly estimated. In addition, the use of annual returns reduces observations in the first-stage regression in the pricing test, which makes the result of this study comparable with that of prior studies. The limitations of this study could be addressed in future research.

\section{References}

Baimukhamedova, A., Baimukhamedova, G., \& Luchaninova, 1. (2017). Financial disclosure and the cost of equity capital: The empirical test of the largest listed companies of Kazakhstan. The Journal of Asian Finance, Economics and Business, 4(3), 5-17.

Ball, R., Gerakos, J., Linnainmaa, J. T., \& Nikolaev, V. (2016). Accruals, cash flows, and operating profitability in the cross section of stock returns. Journal of Financial Economics, 121(1), 28-45.

Bernard, V. L., \& Thomas, J. K. (1989). Post-earningsannouncement drift: Delayed price response or risk premium? Journal of Accounting Research, 27, 1-36.

Bernard, V. L., \& Thomas, J. K. (1990). Evidence that stock prices do not fully reflect the implications of current earnings for future earnings. Journal of Accounting and Economics, 13(4), 305-340.

Campbell, J. Y. (1991). A Variance Decomposition for Stock Returns. The Economic Journal, 101(405), 157-179.

Callen, J. L., Livnat, J., \& Segal, D. (2006). The information content of SEC filings and information environment: A variance decomposition analysis. The Accounting Review, 81(5), 1017-1043.

Callen, J. L., \& Segal, D. (2004). Do accruals drive firm-level stock returns? A variance decomposition analysis. Journal of Accounting Research, 42(3), 527-560.

Callen, J. L., \& Segal, D. (2010). A variance decomposition primer for accounting research. Journal of Accounting, Auditing \& Finance, 25(1), 121-142.

Chae, S.-J., Nakano, M., \& Fujitani, R. (2020). Financial reporting opacity, audit quality and crash risk: Evidence from Japan. The Journal of Asian Finance, Economics and Business, 7(1), 9-17.

Core, J. E., Guay, W. R., \& Verdi, R. (2008). Is accruals quality a priced risk factor? Journal of Accounting and Economics, 46(1), 2-22.

Dang, H. N., \& Tran, D. M. (2019). Relationship between accrual anomaly and stock return: The case of Vietnam. The Journal of Asian Finance, Economics and Business, 6(4), 19-26

Dechow, P., \& Dichev, I. (2002). The quality of accounting and earnings: The role of accrual estimation errors. The Accounting Review, 77(1), 35-59.

Doyle, J., Ge, W., \& McVay, S. (2007). Determinants of weaknesses in internal control over financial reporting. 
Journal of Accounting and Economics, 44(1-2), 193-223.

Easley, D., \& O'Hara, M. (2004). Information and the cost of capital. The Journal of Finance, 59(4), 1553-1583.

Elton, E. J. (1999). Expected return, realized return, and asset pricing tests. The Journal of Finance, 54(4), 1199-1220.

Fama, E. F., \& French, K. R. (1993). Common risk factors in the returns on stocks and bonds. Journal of Financial Economics, 33(1), 3-56.

Fama, E. F., \& French, K. R. (1997). Industry costs of equity. Journal of Financial Economics, 43(2), 153-193.

Francis, J., LaFond, R., Olsson, P., \& Schipper, K. (2005). The market pricing of accruals quality. Journal of Accounting and Economics, 39(2), 295-327.

Lakonishok, J., Shleifer, A., \& Vishny, R. W. (1994). Contrarian investment, extrapolation, and risk. The Journal of Finance, 49(5), 1541-1578.

Leila, A., Mahdi, S., \& Ali, M. (2014). Incremental information content of cash flow and earnings in the Iranian capital market. Journal of Industrial Distribution \& Business, 5(1), 5-9.

Lyle, M. R. (2019). Information quality, growth options, and average future stock returns. The Accounting Review, 94(1),
271-298.

McNichols, M. F. (2002). Discussion of the quality of accruals and earnings: The role of accrual estimation errors. The Accounting Review, 77(s-1), 61-69.

Mohanram, P. S. (2005). Separating winners from losers among low book-to-market stocks using financial statement analysis. Review of Accounting Studies, 10(2-3), 133-170.

Nam, H.-J. (2019). The effect of earnings quality on financial analysts' dividend forecast accuracy: Evidence from Korea. The Journal of Asian Finance, Economics and Business, 6(4), 91-98.

Ogneva, M. (2012). Accrual quality, realized returns, and expected returns: The importance of controlling for cash flow shocks. The Accounting Review, 87(4), 1415-1444.

Petkova, R., \& Zhang, L. (2005). Is value riskier than growth? Journal of Financial Economics, 78(1), 187-202.

Sohn, K.-W., \& Liu, W.-S. (2015). The price of risk in the Korean stock distribution market after the global financial crisis. Journal of Distribution Science, 13(5), 71-82.

Vuolteenaho, T. (2002). What drives firm-level stock returns? The Journal of Finance, 57(1), 233-264. 